\title{
Genome size variability of the population of Gymnadenia conopsea (Orchidaceae) in the Novosibirsk Region (Russia)
}

\author{
Alexandra Nabieva ${ }^{1 *}$, Yulianna Zaytseva ${ }^{1}$, and Nana Shakarishili ${ }^{2}$ \\ ${ }^{1}$ Central Siberian botanical garden SB RAS, 630090 Novosibirsk, Russia \\ ${ }^{2}$ Institute of Botany, Ilia State University, 0105 Tbilisi, Georgia
}

\begin{abstract}
Gymnadenia conopsea (Fragrant orchid) is a widespread model species for the study of polymorphism in the European part of Russia and abroad. Flow cytometry refers to rapid methods effective for assessing the structure of a population by DNA size estimation. However, this method is only available in habitats with close proximity to the place of the experiment, because this indicator is determined only in fresh leaves. A small population of $G$. conopsea in the industrial area adjacent to the Novosibirsk urban agglomeration in the Novosibirsk Region (NR) was studied. Only diploids were detected in the G. conopsea cenopopulation occurred in the industrial zone of the NR. In this study we pointed on significance of genome size variation, which correlates with the adaptive evolution of the G. conopsea in West Siberia. The revealed absence of minor cytotypes (individuals with a higher level of ploidy) in G. conopsea population reduces intraspecific and intrapopulation diversity of the species.
\end{abstract}

\section{Introduction}

Gymnadenia conopsea (L.) R. Br. is a polycarpous tuberous species with erect aerial shoots, which is widespread throughout Eurasia $[1,2]$. G. conopsea constitutes a significant part of the orchid flora from the temperate zone and becomes a model species for studying the effect of ploidy changes on the plant organism [3]. However, genome size of the orchid species has not been investigated in Asiatic part of Russia in natural environments. Meanwhile, investigators successfully applied genome size data in determination of levels of genetic diversity of threatened plant species [4] and identification of species [5]. But studies relating plant genome size variation to adverse environmental conditions are scarce [6].

In Russia at the beginning of the 21st century, excessive anthropogenic load caused a decrease in the number and size of cenopopulations (CP) of G. conopsea [7]. Plants of this species are protected by law in several regions of Russia [8, 9]. Previous studies in Europe revealed genetic differentiation $[10,11]$ in mixed ploidy $\mathrm{CP}$, where diploid and tetraploid individuals predominate [12]. G. conopsea was considered to belong to the group of plants

\footnotetext{
* Corresponding author: $\underline{\text { sibflower05@gmail.com }}$
} 
with different cytotypes, which serve as a reserve for an increasing the intraspecific diversity of $G$. conopsea [13].

While some researchers remained of the view that the basic chromosome counting of G. conopsea is $\mathrm{x}=10$ [2], higher ploidy levels were deduced [14]. With the assumption that the haploid number for $G$. conopsea is $\mathrm{x}=20$, the diploid level was confirmed by the counting $2 n=40$, recorded for some specimen from the populations in Central Europe [13] and for the Northwestern Russia [14]. Tetraploid plants were not discovered among samples from Northern Europe (Sweden, Estonia), along with the plants from the parts of Russia [15].

The aim of the research was to estimate genome size diversity among the individuals in the local CP by the analysis of chromosome numbers and flow cytometryUse $170 \times 250$ $\mathrm{mm}$ paper size (W $\mathrm{x} \mathrm{H} \mathrm{mm}$ ) and adjust the margins to those shown in the Table 1. The final printed area will be $130 \times 210 \mathrm{~mm}$. Do not add any page numbers.

\section{Materials and methods}

The study was carried out in natural conditions in the surroundings of Linevo, Novosibirsk Region (NR), Russia. The cenopopulation (CP) in 2019 consisted of no less than 30 generative individuals and it is found at $190 \mathrm{~m}$ elevation, N $54^{0} 27^{\prime} 42$ "; E 83 $20^{\circ} 42^{\prime \prime}$. Identification of species was done in accordance with I. M. Krasnoborov [16]. Ten randomly chosen generative specimens were used for chromosome counting. The species occurs in the vicinity of Novosibirsk Electrode Plant and is affected by its aerosol emissions which were recently analysed [17]. To prepare samples for FSM analysis the young leaves of $5 \mathrm{G}$. conopsea representatives were used. To avoid analyzing plants from the same clone, the samples were collected from individuals, separated from each other not less than 5 meters.

\subsection{Flow cytometry analysis}

The relative DNA content (2C) and genome size was performed by use of flow cytometry (FCM) analysis with CyFlow ${ }^{\circledR}$ Space (Partec, Germany). Pisum sativum L. 'Ctirad' (2C = $9.09 \mathrm{pg}$ ) [18] was selected as reference standard, as it has a genome size close to that of most Gymnadenia samples, but not overlapping it. The samples for FCM analysis were prepared according to [19] using Partec CellTrics filters (Sysmex Partec GmbH, Germany) with $100 \mu \mathrm{M}$ of pore size. The $2 \mathrm{C}$ and genome size was calculated as described in [20, 21]. To analyze the data obtained, the FloMax 2.9 software package (Partec, Germany) was used.

\subsection{Squashed temporary preparations}

Squashed temperate preparations were made from root tips for chromosome evaluations of mitotic states according [22]. The prepared slides were immediately observed under Axioskop-40 imaging microscope and images captured using AxioVision 4.8 digital image processing software.

\subsection{Statistical analysis}

All experiments consisted of three independent replicates. Standard errors (SE) of the genome size evaluations of $G$. conopsea specimens were analyzed using STATISTICA 8 software (StatSoft Inc., Tulsa, OK 


\section{Results and discussion}

All samples studied were found to be diploids. The FCM profiles indicated stability of the ploidy level in leaf cells of the samples. Relative genome sizes (2C) of the genotypes ranged between $5.17 \mathrm{pg}$ and $5.51 \mathrm{pg}$, consequently 1C varied from 2526.07 to 2692.36 Mbp, average values being 5.30 pg and 2591.06 Mbp, respectively (Table).

Table. Determination of genome size and relative DNA content of Gymnadenia conopsea individuals from the Novosibirsk region cenopopulation

\begin{tabular}{|c|c|c|c|}
\hline № of sample & $\mathbf{2 C}^{\mathbf{a}} \mathbf{p g}$ & $\mathbf{1 C}^{\mathbf{b}}, \mathbf{p g}$ & Genome size, Mbp \\
\hline 1 & 5.17 & 2.58 & 2526.07 \\
\hline 2 & 5.32 & 2.66 & 2601.12 \\
\hline 3 & 5.25 & 2.62 & 2566.61 \\
\hline 4 & 5.25 & 2.63 & 2569.13 \\
\hline 5 & 5.51 & 2.75 & 2692.36 \\
\hline Mean & 5.30 & 2.65 & 2591.06 \\
\hline Standard error (SE) & 0.06 & 0.03 & 31.29 \\
\hline
\end{tabular}

a $2 \mathrm{C}$ - diploid DNA content, pg.; ${ }^{\mathrm{b}} 1 \mathrm{C}$ - haploid DNA content, pg.

Chromosome preparations of G. conopsea reported in [5] and [14] showed that in CP in Russia it had $2 \mathrm{n}=40$. While in the mountain regions of Central Europe the two major cytotypes (diploid and tetraploid) in G. conopsea populations were verified and often revealed simultaneously [23]. According to researchers, who assessed the basic chromosome number of $G$. conopsea as $\mathrm{x}=20$ [5, 13], our own chromosome counting among $G$. conopsea individuals from the studied CP comprised only diploids, and determination of the species ploidy level by means of FCM successfully approved these findings.

Our study provided confidence that in the analyzed samples ploidy level was correctly identified by the assumption that relative DNA content corresponds to the definite ploidy level. Earlier, during the analysis of orchid species from the Central Europe CP, the genome size (1C-value) of G. conopsea individuals was determined as $5.51 \mathrm{pg}$ [24]. Owing to the lack of chromosome counting in the above mentioned article, the estimated genome size data for $G$. conopsea specimen from local European population could indicate tetraploidy level $(4 \mathrm{x})$ of these individuals. This value is not in concordance with our data (the studied G. conopsea plants genome size was assessed as $2.65 \mathrm{pg}$ for $1 \mathrm{C}$ DNA relative content).

While under undisturbed conditions in the northern regions of Russia, G. conopsea populations with different cytotypes are existing, we revealed the lack of genome size variability among studied individuals in the cenopopulation occurred in the industrial zone of the NR. It is considered that mixploid populations, which have wide genetic variation, are more resistant to harmful environment [25]. According to [26], G. conopsea belongs to the plants with intermediate genome size, included long-lived and slow-growing plants with limited ability to survive in stressful conditions.

Tetraploids also show higher mycorrhizae fungal colonization rates thus host plants could gain greater benefits from associated symbionts, than diploids [27]. On the other hand, suppression of the rhizosphere inhabitants by any kind of pollution may lead to dramatic changes in diploid-tetraploid orchid ratios. 
The results confirm the findings, which demonstrated significant decrease of plants with intermediate and large genome sizes in $\mathrm{CP}$ endured under the increasing impact of heavy metal pollution [28].

Thus, it can be assumed that $G$. conopsea specimen genome size is probably associated with the species adaptive potential. The non-occurrence of different cytotypes in $G$. conopsea $\mathrm{CP}$ indicated that the species possesses low resistance to environmental pollution.

So far, flow cytometry coupled with chromosome counting proved to be efficient technique in $G$. conopsea ploidy level and genome size determination.

\section{Conclusions}

Due to the complex genome analysis in the studied CP from Novosibirsk region we revealed only diploid cytotypes within $G$. conopsea samples. It was considered that the assessed low variation in genome size makes this local CP heading towards the extinction. Further efforts for the conservation of this low-size G. conopsea CP should focus on the vast biological treatment based on both molecular and morphological data as well as monitoring environmental conditions.

The reported study was carried out with the financial support of the budgetary project "Analysis of biodiversity, conservation and restoration of rare and resource plant species using experimental methods" No. AAAA-A21-121011290025-2 within the framework of the State Assignment.

\section{References}

1. R. Soó, Orchis L. Flora Europaea, V (Cambridge University Press, Cambridge, 1980)

2. T. Meekers, M. J. Hutchings, O. Honnay, H. Jacquemyn, J. of Ecol. 100 (2012)

3. T. Kettunen, P. Uotila, Memoranda Soc. Fauna Flora Fenn. 95 (2019)

4. R. Leimu, P. I. A. Mutikainen, J. Koricheva, M. Fischer, Ecology, 94 (2006)

5. K. Kraaijeveld, Evol. Biol. 37 (2010)

6. A. Carta, L. Peruzzi, New Phytol. 210 (2016)

7. P.G. Efimov, Russian J. Genet. 49 (2013)

8. The Red Book of Murmansk Region (Aziya-Print, Kemerovo, 2014)

9. The Red Book of the Republic of Komi (Komi Book Publishing House, Syktyvkar, 2019)

10. S. Gustafsson, M. Lönn, Heredity (Edinb) 91 (2003)

11. P. Trávnicek et al, Ann. Bot. 110 (2012)

12. J. Jersáková, S. Castro, N. Sonk, K. Milchreit, I. Schödelbauerová, T. Tolasch, L. S. Dötter, Evol. Ecol. 24 (2010)

13. M. Soliva, A. Widmer, Int. J. Plant Sci. 160 (1999)

14. P. Trávníček, B. Kubátová, V. Curn, J. Rauchová, E. Krajníková, J. Jersáková J. Suda, Ann. Bot. 107 (2011)

15. D. A. Krivenko, S. G. Kazanovsky, A. V. Verkhozina, O. D. Chernova, O. S. Dymshakova, A. L. Turskaya, Taxon 62 (2013)

16. I. M. Krasnoborov, M. N.Lomonosova, D. N. Shaulo, E.I . Vibe, O. S. Zhirova, E. A. Korolyuk, A. A. Krasnikov, O. N. Snytko, N. N. Tupitsyna, Keys to plants of the Novosibirsk region (Nauka, Novosibirsk, 2000) 
17. V. F. Raputa, V. V. Kokovkin, O. V. Shuvaeva, Aerosol impurities sedimentation monitoring in the vicinity of Novosibirsk electrode making plant, in Proceedings of the 25th International Symposium on Atmospheric and Ocean Optics, 30 Jun - 5 Jul 2019, Novosibirsk (2019)

18. J. Doležel, J. Greilhuber, S. Lucretti, A. Meister, M. Lysak, L. Nardi, R. Obermayer, Ann. Bot. 82 (1998)

19. Y. G. Zaytseva, E. V. Ambros, A. V. Karakulov, T. I. Novikova, Bot. Pac. 7 (2018)

20. J. Doležel, J. Greilhuber, J. Suda, Nat. Protoc. 2 (2007)

21. J. Doležel, J. Bartoš, H. Voglmayr, J. Greilhuber, Cytometry 51 (2007)

22. A. A. Krasnikov, Problems of karyology, karyosystematics and molecular systematics of plants (Novosibirsk, CSBG, 2004)

23. C. Stark, S. G. Michalski, W. Babik, G. Winterfeld, W. Durka, Plant Syst. Evol. 293 (2011)

24. S. Siljak-Yakovlev, F. Pustahija, E. M. Šolić, F. Bogunić, E. Muratović, N. Bašić, O. Catrice, S. Brown, Adv. Sci. Lett. 3 (2010)

25. Van de Peer, T-L. Ashman, P. S. Soltis, D. E. Soltis, Plant Cell 33 (2021)

26. M. Rewers, I. Jedrzejczyk, A. Rewicz, A. Jakubska-Busse, Genes. 12 (2021)

27. T. J. Anneberg, K. A. Segraves, Am J Bot 106 (2019)

28. E. Temsch, W. Temsch, L. Schratt-Ehrendorfer, J. Greilhuber, J Bot Article (2010) 